\title{
Gondolatok az építészetszociológia és a szociológia viszonyáról ${ }^{1}$
}

\author{
Tamáska Máté \\ https://doi.org/10.51624/SzocSzemle.2020.1.1 \\ Beérkezés: 2020.01.13. \\ Átdolgozott változat beérkezése: 2020.04.07. \\ Elfogadás: 2020. 04.09.
}

\begin{abstract}
Összefoglalás: A tanulmány az építészetszociológia és a szociológia viszonyát egyetlen központi kategória, az építészeti cselekvés fogalma alapján tárgyalja. E fogalom kifejezi, hogy az épített környezet nem csupán háttere, színpada, lenyomata a társadalmi viszonyoknak, hanem a társadalmi interakciók aktív ágense. Az építészet tehát nem lehet neutrális szereplő a társadalomban, hanem hierarchiaviszonyokat, szegregációkat, szerepeket definiál, társadalomformáló jelleggel bír, elválaszthatatlan a társadalmi cselekvés egyéb (például verbális) formáitól. Hogy mindez miként valósul meg, arra a tanulmány három elméleti megközelítést is idéz, Delitz, Steets és Fischer munkáit. Delitz szerint a társadalom kollektív makrofolyamatai, intézményei azok, amelyek nem létezhetnek építészeti forma nélkül. Delitz az építészet tárgyát is kitágítja, és a szociológia számára értelmezhetőbb épített környezetről beszél. Steets elmélete mikroszintről indul, és az építészet létrejöttének, befogadásának és szocializációjának (objektív valóság) hármasságában ragadja meg az építészeti cselekvés lényegét. Steets érdeme, hogy tág kaput nyit a bevált szociológiai módszertani eljárások előtt. Végül Fischer a két szerzőt kiegészítve az építészet sajátosságaiból indul ki, mikor időtálló, stabil társadalmi médiumként tekint az építészetszociológia tárgyára. Az idézett építészetszociológiai elméletek közös következtetése, hogy a weberi társadalmicselekvés-fogalmat ki kell egészíteni a materiális környezet vizsgálatával, sőt a szociológia paradigmaváltására is szükség lenne. A dolgozat ezzel szemben amellett érvel, hogy az építészetszociológia céljának nem egy a szociológián belüli paradigmaváltásnak kell lennie, hanem egy interdiszciplináris párbeszéd megteremtésének. Nem egy klasszikus értelemben vett szakszociológiára van tehát szükség, hanem az építészet humán oldalát megvilágító tudományközi mezőre.
\end{abstract}

Kulcsszavak: építészetszociológia, az építészeti cselekvés, épített környezet, az építészet humán olvasata

A hazai társadalomtudományos diskurzusban az építészetszociológia viszonylag ritkán használt szóösszetétel. Ha fel is bukkan egymás mellett a szociológia és az építészet, azokat rendszerint egymástól független változóként kezelik, mikor például a városképek alakulásának hatótényezőit szokás felsorolni. Első ránézésre az építészetszociológia a térrel foglalkozó bevett szakszociológiák sorába illeszthető be, mint például a terve-

1 A tanulmány az „Építészetszociológiai tanulmányok" Bolyai János Kutatói Ösztöndíj program keretében született, az Eötvös Loránd Kutatási Hálózat, Társadalomtudományi Kutatóközpont Magyar Tudományos Akadémia Kiváló Kutatóhely Szociológiai Intézetében. 
zésszociológia, a városszociológia, a lakásszociológia, esetleg az építészszerepek miatt az értelmiségszociológia felé orientálódva. Az alábbi írás ezzel szemben amellett érvel, hogy ellentétben az iménti szakszociológiákkal, az építészetszociológia nem a szociológián belül, hanem annak határmezsgyéjén helyezkedik el. Ennek igazolására a kortárs német elméleti építészetszociológia szerzőinek a társadalmi cselekvés fogalmát újragondoló téziseiből indulok ki. Ám míg az idézett szerzők végkövetkeztetése az, hogy az építészetszociológia a szociológiai megismerés egészét átalakíthatja, véleményem szerint sokkal inkább egy, a társadalom térbeliségét vizsgáló határtudomány van születőben.

\section{A német építészetszociológiai iskola}

Jelen írásban nem vállalkozhatok arra, hogy teljes egészében áttekintsem a születő tudományterület valamennyi irányzatát és törekvését. ${ }^{2}$ Ehelyett egy szervezetileg is jól látható, a tudományos publikációk terén különösen aktív csoport munkáira támaszkodom majd. A német szociológiai társaságon belül a kétezres évek elején szerveződött meg az építészetszociológiai munkacsoport (Arbeitsgemeinschaft Architektursoziologie, alapítva 2007-ben), vezetői: Heike Delitz és Silke Steets. ${ }^{3}$ Az írás elsősorban az ő elméleti alapvetéseiket mutatja be, támaszkodva Joachim Fischer értelmezésére, aki a két szerző közötti alapvető különbségekre helyezte a hangsúlyt, majd saját elméleti szintézissel állt elő.

Mielőtt azonban rátérnénk a részletes elemzésre, érdemes feltenni a kérdést, vajon a kutatók személyes érdeklődésén túl lehettek-e egyéb okai a németországi építészetszociológia viszonylag sikeres kodifikálásának. A válasz hipotetikus, de talán nem haszontalan. Németországban jó néhány évtizede állandó és sokak által tárgyalt politikai viták tárgya az építészet. A kilencvenes évek eleje a lakótelepek jövőjéről szólt, majd a berlini kormányzati negyed újjáépítése, illetve az NDK állampárt építészeti öröksége került a fókuszba. A legutóbbi időkben Drezda turisztikai célú újjáépítése adott olyan témát, amely szélesebb közönséget megmozgatott, és amelyben az építészet és a politikai értékrend, a történelmi múlthoz való viszony stb. óhatatlanul összekeveredett (Helms 1992; Will 2008; Brenner 2017). Az elmúlt három évtized Németországának építészeti érdeklődéséhez hasonló intenzitású vitákat Magyarországon legfeljebb a negyvenes-ötvenes években tapasztalhattunk (ekkor is felülről irányítottan), amikor is a kommunista diktatúra társadalomépítő szerepet jelölt ki az „állam mérnökeinek” (Keller 2017: 62). Nem állítom persze, hogy a németországi közbeszéd iménti témái közvetlen okai lennének az építészetszociológia intézményesülésének. Annyi viszont látható, hogy a közbeszéd tematikáinak köszönhetően az építészetszociológia relevanciája nem igényelt külön magyarázatot: minden ilyen jellegú kutatás egyben aktualitásként társadalmi kérdésekre is választ keresett.

2 Az építészetszociológia tudománytörténeti előzményeiről lásd Schäfers 2003; 2012.

3 Lásd a társaság honlapját: http://www.heike-delitz.de/Index\%20archsoz.html (letöltés: 2020. január 3.) 
Elöljáróban még egy fontos megjegyzést szeretnék tenni, amely részben előrevetíti az elemzés szerkezetét is. Az alább bemutatott német építészetszociológiai iskola elsősorban elméleti alapokon nyugszik. Ez korántsem magától értetődő, ha belegondolunk, hogy éppen az építészethez kötődő társadalomtudományos vizsgálatokban szinte korlátlan számú kutatási lehetőség kínálkozik, nem beszélve az alkalmazott kutatások, a beruházási és múemléki hatásvizsgálatok, a közösségi tervezési alkalmak sokaságáról (Szelényi 1973; Csanádi et al. 2010; Csurgó 2014; Karstein - Schmidt-Lux 2017; Kőszeghy 2019). Ám éppen az elméleti megalapozottsága okán a német építészetszociológia két igen jelentős tudománytörténeti eredményt ért el. Az egyik, hogy - részben saját szociológiai státuszát legitimálandó - újraértelmezte a szociológiatörténet klasszikusait, mindenekelőtt az alapítókként kodifikált Émile Durkheimet és Georg Simmelt, de gyakran hivatkoznak Norbert Elias, Michel Foucault vagy Pierre Bourdieu munkáira is (Fischer-Delitz 2009). Ennek eredményéről itt nem lesz mód bővebben írni. A másik, legközvetlenebbül elméleti igényű törekvésről annál inkább, amely a szociológiai cselekvés újradefiniálását tűzte ki célul. Az építészet szociológiai vizsgálata ugyanis megköveteli, hogy az épített környezetet ne csupán az interakciók színpadaként fogjuk fel, hanem a társadalmi viszonyokat rögzítő, azokat egyben alakító, aktív cselekvőként határozzuk meg (Karstein - Schmidt-Lux 2017: 3). A következőkben arra keresem a választ, hogy milyen utakat talált a német építészetszociológia a magyarul talán cselekvő építészetnek nevezhető problémakörben.

\section{A cselekvő építészet}

Joachim Fischer a vallási élet anyagisága kapcsán született tanulmányában élesen elválasztja egymástól a szociológia bevett hagyományaihoz ragaszkodó térelméleteket az újabb építészetszociológiai iskolától (Fischer 2017: 51; a térelméletekről lásd bővebben Hidas 2013; Berger 2018). Előbbire a német térszociológia klasszikusát, Martina Löwöt hozza fel példának, aki elméleti munkáiban a teret olyan szociális konstrukcióként értelmezi, amelyben annak anyagi megformáltsága nem játszik lényeges szerepet (Löw 2001). Másként fogalmazva Löw a térben lejátszódó társadalmi folyamatokat vizsgálja, és nem a térbeliség társadalmiságát. Fischer nem hoz példát, de Simmel (1957) „híd”-esszéjéből kiindulva a következőket mondhatjuk. A híd szociológiai értelemben az integráció, az összetartozás térbeli kifejeződése. Ugyanakkor Simmel arra már nem tér ki, hogy a hídnak, mint építészeti alkotásnak vannak olyan sajátos tulajdonságai, amelyek ezt a szerepet árnyalhatják. Márpedig ha egy híd társadalmi identitásformáló jellegét akarjuk megérteni, akkor figyelembe kell venni a stílusát, a korát, az esztétikai megjelenését, sőt a teherbírását is. Gondoljunk csak az 1945 előtti és az újjáépített Erzsébet híd közötti markáns különbségre. Míg az eredeti híd a századfordulós városegyesítés kulturális öröksége volt, a hatvanas évek elején átadott új kábelszerkezet a maga korszerú technológiájával a modernizálódó (a maga módján nyugatiasodó) szocializmust képviselte. Egy olyan átalakulást, amelynek során 
a politikum a szimbólumok (szobrok, reprezentatív építészet) felöl a teljesítmények (tömeges lakásépítés, útépítés) felé mozdult el (Tamáska 2018: 71). Ehhez jön még a híd tényleges kapacitása, amely idővel lehetővé tette a hazai kelet-nyugati autópályák forgalmának belvárosba terelését (Miklóssy 1995 o. n.). A növekvő forgalom kihatott a belváros kereskedelmi és lakónegyed jellegére is, és vele a városi életmód átalakulására. Ha tehát mindkét mérnöki alkotást egyszerűen „hídként” definiálnánk, éppen a cselekvő építészet fogalmában rejlő finom megfigyelések lehetősége veszne el.

Ahhoz, hogy az alábbiakban a német szerzők munkáit idézve részletesen is megvizsgáljuk az építészeti cselekvés értelmezésének lehetséges módozatait, az iménti példákat általánosítva érdemes egy munkahipotézis-szintű definícióját megadni a fogalomnak. A cselekvő építészet fogalmán tehát azt értjük, hogy az épített környezet része a társadalmi interakcióknak, normákat közvetít és jelenít meg, találkozásokat generál vagy éppen tesz lehetetlenné, befolyásolja a használók alaphangulatát, attitűdjeit. Ugyanakkor az építészeti cselekvés nem állítja, hogy az építészeti forma determinálná a használatot. Az építészeti cselekvés vizsgálatára egy külön szakdiszciplína, az építészetszociológia vállalkozik, amely önálló elméleti igénnyel lép fel a szociológián belül, de annak határterületein mozogva.

Fischer az építészetszociológiai elméletek kapcsán kritériumként határozza meg, hogy azok a szociológia mellett az építészetet a maga tárgyszerűségében is megértsék. Fischer szerint Delitz és Steets erre jó példák, noha más-más stratégiát kínálnak. Delitz a makroszint felől közelít, és az építészetet a társadalom kollektív cselekvéseként értelmezi, míg Steets a mikroszint felől indul, és az építészet létrejöttének folyamatát állítja a középpontba. A továbbiakban Fischer gondolatmenetéhez kapcsolódva, de az idézett szerzők saját munkáira támaszkodva mutatom be a kétféle építészetszociológiai cselekvéselméletet.

Delitz (2009; 2010) az építészeti és a társadalmi cselekvés elválaszthatatlanságából indul ki. Amikor például a modern építészet a 20. század elején fellázad a historizmus „stíluskáosza” ellen, voltaképpen a társadalmi anarchia és értékválság ellen emel szót (Delitz 2009: 7). Ám miközben az építészeti elméletalkotás nagyon is erőteljes társadalomkritikai igénnyel lép fel, az ugyanezekben az évtizedekben intézményesülő szociológia tudatosan igyekszik elhatárolódni a fizikai tények megfigyelésétől (i. m. 11.). Eßbach (2001: 132) szerint a 19. század technikai forradalma és a mindennapokat elárasztó tárgyak sokasága olyan kihívás elé állította a humán tudományok képviselőit, amelyre a többség a társadalmasodás materiális és technikai oldalának a kizárásával válaszolt. A szociológia igyekezett a fizikai, a technikai, a biológiai stb. perspektívától függetlenül létező narrációt alkotni. Delitz könyvében a ma is széles körben elterjedt Max Weber-féle társadalmicselekvés-fogalmat hozza fel példának, amely tudatosan vak az épített környezetre: „Társadalmi cselekvésnek [...] az olyan cselekvést nevezzük, amely a cselekvő vagy a cselekvők által szándékolt értelme szerint mások viselkedésére van vonatkoztatva, és menetében mások viselkedéséhez igazodik." (Farkas 2006: 42). Weber és követői szerint a szociológia feladata kizárólag az emberek közöt- 
ti interakciók vizsgálatára terjed ki. Még az építészetszociológiához legközelebb álló városszociológiai iskola is, élén a sokat idézett humánökológiai modellel, olyan elvont fogalmakat alkotott, amelyek nélkülözték az adott város sajátos építészeti hagyományait (Delitz 2009: 115).

Az iménti állítás megértéséhez egy közismert városszociológiai fogalomra utalok: a szegregációra. A városszociológia bevett értelmezése szerint a szegregáció a „fejekben" (attitűdökben) létrejövő elhatárolódásként jelenik meg, amely együtt jár a térbeli elkülönüléssel. ${ }^{4}$ Ám az elkülönülés technikai kivitelezésének elemzése már nem tartozna a városszociológiai vizsgálat tárgyához. Holott ha elképzelünk egy 19. századi gangos bérház ${ }^{5}$ és egy mai lakópark kínálta térrendszert, látható, hogy míg elóbbiben az elkülönülést a társadalmi rituálék (megszólítási formák, lépcsőhasználat ideje és módja stb.) szolgálták, a mai lakóparkban a kerítés egymaga helyettesíti ezeket a viselkedésformákat (Csizmady 2008: 161). Az építészetileg is elzárt szegregátumokban nincsenek napi interakciók a különféle társadalmi státuszú emberek között. Ez azonban azzal is jár, hogy a szocializáció során nem alakulnak ki olyan rituálék, amelyek biztosíthatnák az eltérő értékrendű, életvitelü, jövedelmű stb. rétegek egymás mellett élését. Ez pedig tovább erősíti a szegregációt, hiszen az egyén a biztonságérzetét veszíti el, ha kilép a védett területről. Davis a lakóparkok, bevásárlóközpontok, autópályák alkotta mai amerikai nagyvárost egyenesen egy erődrendszerhez hasonlítja (Davis 1999).

Visszatérve Delitz építészetszociológiai téziseihez fontos látni, hogy az építészet nem egyszerűen tükre vagy lenyomata a társadalomnak - ezt a klasszikus szociológiai elméletek sem vitatnák -, hanem a társadalmi cselekvés része. A múvi környezet elemei, amikor tagolják, elválasztják és összekötik a tereket, azokat sajátos funkciókhoz és szerepekhez rendelik, voltaképpen a társadalom szerkezetének és intézményeinek szerves alkotóelemeit hozzák létre. Mindennapi gondolkodásunk számára mindez magától értetődő, hiszen például a modern orvoslást kórházak nélkül, az oktatást iskolák nélkül elképzelni sem tudjuk. Ahhoz azonban, hogy mindezt módszertanilag is érvényesíteni tudjuk, ki kell tágítani az építészet határait, és a legtágabb értelemben vett épített környezetként kell értelmezni azt (Delitz 2009: 19). És itt nem csak arról van szó, hogy a nagy múvészeti alkotások mellett a tömegépítészetet vagy másként anonim építészetet is figyelembe kell venni, hanem arról, hogy az olyan, építészetnek alig nevezhető térstrukturáló tárgyak is fontosak lehetnek, mint például a sátor, az árok vagy egy egyszerű pásztorbot. ${ }^{6}$ Az építészeti elemek szabályozzák a cselekvés irányát, irányítják a látványt, kiemelnek és eltakarnak, s ezzel tematizálják a társadalmi

4 Noha a városökonómiai modell finomítása során igyekeztek figyelembe venni bizonyos földrajzi adottságokat (Berki 2014: 43), ezek mégsem oldották fel az alapproblémát, miszerint a lakóhelyi elkülönülés társadalomtechnikái nemcsak jogi és gazdasági (tehát elvont, szövegszerü tények), hanem építészeti jelenségek is.

5 A bérházak és általában az építészeti terek társadalmi összefüggései kapcsán iskolateremtő hatású volt Bobek és Lichtenberger (1966) Bécsről megjelent munkája.

6 Ez a gondolkodásmód az építészetelmélettől sem áll távol, igaz, ott a térformálás elemi eszközeiként egy alaktani tipológia alapelemeiként, geneziseként szerepelhetnek ezek az egyszerū tértagolási eljárások (Meggyesi 2009). Másfelől viszont építészetszociológiailag sem lényegtelen, hogy például egy-egy építészeti elem milyen technológiával, milyen anyaghasználattal készül. Mindez utalhat az adott társadalmi intézmény tartósságára, rangjára, beágyazottságára. 
cselekvést. Az építészet persze nem úgy vesz részt a társadalmi folyamatokban, mint azt a 20. század közepén sokan gondolták, azaz nem determinálja a cselekvést, hanem csupán irányokat szab.

Jellegzetes problémaként merült fel akkoriban, hogy a modern lakókörnyezet nem teremtett automatikusan modern embert. Az ötvenes-hatvanas évek városi kislakásaiba költöző első generációs vidéki népesség számára a „jól méretezett” helyiségek ellenére kellemetlenül szúk volt a konyha és a kamra. Az építészeti szándék világos volt: a munkavállaló háziasszony (és családja) amúgy is az üzemi étkezdébe jár, az otthoni élelmiszer feldolgozása ezért minimális helyet igényel. Az eredmény azonban az lett, hogy az örökölt szociális minták még jó ideig fennmaradtak, ami rendkívüli zsúfoltsághoz vezetett (Keller 2017: 193). Ami az ötvenes-hatvanas évek lakástervezésében történt, az nem volt más, mint egy társadalmi utópia felépítése fizikai környezetként. A soron következő építészetszociológiai kérdés ezzel kapcsolatban az lehetne, hogy ez a megvalósult utópia miként járult hozzá a következő nemzedékek valós életmódjának és a női szerepeknek a változásához? A kis konyha ugyanis egy személynek is szúk volt, de azt végképp megnehezítette, hogy a háziasszony a felnövekvő gyerekeit is bevonja a munkába, így hosszú távon mégiscsak hozzájárulhatott a modernizáció folyamatához.

Az iménti példa azon túl, hogy igyekezett rávilágítani az építészeti cselekvésnek a mindenkori normarendszer alakulásában játszott szerepére, utalt az építészeti cselekvés sajátos időviszonyaira is. Castoriadisra utalva Delitz (2008: 5832) hangsúlyozza, hogy az építészet az állandóan változó társadalom stabilitásigényének kifejeződése, hiszen azt a képzetet kelti, mintha a környezet eleve adott, az egyes embertől függetlenül létező valóság lenne. Relatív stabilitása teszi, hogy az építészeti változások egyben a társadalom kollektív értékeinek, normáinak és makroszociológiai folyamatainak a lenyomatai. Miközben Delitz az építészetet mint a kollektív társadalmi cselekvés részét határozza meg, a Fischer (2017: 52) által idézett másik szerző, Steets az egyéni cselekvő szemszögéből kiindulva alkotja meg elméletét.

Steets számára nem az a fő kérdés, hogy a kollektív cselekvés és az építészeti cselekvés egymásba olvad, hanem az, miként zajlik ez az összefonódás. Másként fogalmazva: miként befolyásolja a tervezőt a társadalmi normarendszer, miként érzékelik az épített környezetet a használók, és végül az építészet miként válik objektív valósággá az adott közösség számára. A létrehozás-befogadás-valóság hármas rendszerét a szerző Peter L. Berger és Thomas Luckmann tudásszociológiai elméletére alapozza (Steets 2015: 49). ${ }^{7}$ Steets kiinduló tézise igen hasonló Delitzéhez: „Az anyagi objektivációk mindennapi élettapasztalatunk szerves részét képezik. Épületekkel és infrastrukturális elemekkel vagyunk körülvéve; naponta használunk szerszámokat, egyéb müvi és

7 A koncepció lényege, hogy az egyén által megélt társadalmi valóságot az egyén és kultúra, illetve társadalmi környezete között fennálló, egymást feltételező értelmezési dinamikák sorozata hozza létre. Az első az externalizáció, mikor is a cselekvő szándéka a környező világ alakítása; a második az internalizáció, a társadalmi szabályok elsajátítása, a harmadik az objektiváció, maga a tárgyiasult valóság, amely azonban sosem független létező, mindig a másik két szint értelmezéseitől függ (Berger Luckmann 1988). 
természetes tárgyakat, tekintetünket látványtengelyek, képi és grafikai elemek irányítják, hangulatunk alapvetöen befolyásolja a környezet, hogy pl. templomban vagy stadionban vagyunk-e?" (Steets 2015: 8). Steets tehát azzal egészíti ki Berger és Luckmann elméletét, hogy az objektivációt nem az immateriális szintjén ragadja meg, mint például a beszéd, az attitűdök, az elvont fogalmak, hanem a kézzelfogható fizikai valóságában. A kérdés annál is inkább érdekes, mert ellentétben például a nyelvi apparátussal, a „naiv” térhasználó az épített környezetet általában reflektálatlanul használja, vagy legalábbis nem tulajdonít neki olyan jelentőséget, mint a nyelvileg megformált kijelentéseknek. ${ }^{8}$ Steets szerint az építészeti tervezés folyamata az a képesség, amely a térbeliség objektív valóságán változtatni képes. Steets itt elsősorban a 20. század modern építészetét hozza fel példaként, mindenekelőtt Gropius munkáit, aki az építészetet az ipari előregyártással kombinálva nemcsak egy új építőtechnikát, hanem új lakásmódot és városképet is teremtett, ahol a családon belüli szerepek, a szomszédság, a munka és a szabadidő mind új objektív formát nyertek. ${ }^{9}$ Steets tehát a múvészi tervezést a kreativitással, a fantáziával, a valóság meghaladásának gyakorlatával azonosítja (Steets 2015: 146).

Itt azonban ki kell egészíteni Steets eredeti koncepcióját azzal, hogy az építészetszociológia számára az építőmúvészet a teljes képnek csupán kis szeletét adhatja. Ha az építés egész folyamatára koncentrálunk, a kreativitás mellett (helyett) előtérbe kerülnek a szocializációs, mintaátvételi, konform jelenségek. Sőt a társadalmi valóság társadalmi létrehozásában ezeknek a folyamatoknak nagyobb jelentőséget kell tulajdonítani, mint a kreativitásnak, hiszen mindennapi településképeinket nem újító múvészek, hanem pallérok, családi házakat tervező mérnökök, kivitelező cégek hozták és hozzák létre. ${ }^{10}$

Visszatérve Steets gondolati ívéhez az építészekkel (teret létrehozók) átellenes oldalon találjuk a térhasználókat (befogadók), akik részben beleszületnek környezetükbe, részben kénytelenek megtanulni új környezeti és vele társadalmi mintázatokat, például egy faluból felköltözött személy egy új típusú lakótelepen. Steets ezt a „világ belakásának” (2015: 2006) nevezi, amely során az egyén szocializálódik a környezetéhez, értelmezési mintákat sajátít el (például arról, hogy milyennek kell lennie egy szép városnak, egy jó lakásnak stb.), de tényleges testi képességeket is megtanul (például a liftek, a mozgólépcsők használatát). A világ internalizálásának kiemelt időszaka kétségtelenül a gyermekkor. Ám építészetileg legalább ilyen érdekesek azok az esetek, amikor egy már megtanult környezeti szocializációs mintázatot írnak át az

8 Ebből adódik egyébiránt az építészetszociológia kutatási dilemmája is. Miközben az életútinterjúk, kérdőívek elemzésekor a válaszadó által közölt narrációk, attitűdök „szociológiai tényként” elfogadandóak, az építészetszociológiában a megfigyelő hozza létre a használó értékorientációját. A már említett szegregáció kapcsán pl. éles ellentétben lehet egy meglehetős nyitottságról valló kitöltött Bogardus skála és az illető magas fallakkal körbezárt, erődszerű otthona valamelyik elegáns kertvárosi villanegyedben.

9 Steets ehhez még hozzáteszi, hogy miközben Gropius forradalmi újdonságokat hirdetett, alapvető szocializációs mintákat nem vett észre. Így például fel sem merült benne, miként a modern építészek java részében sem, hogy a konyha lehetne más is, mint tisztán „női territórium”.

10 Fontos megjegyezni, hogy az építészet más múvészeti ágakkal szemben különösen konzervatív múfaj. S bár az építészeti kritikákban (laudációkban) divatos „kísérletezésről” beszélni, a valóság az, hogy az építés túlságosan drága ahhoz, hogy az építtető "kísérletekre” adja a megtakarított pénzét. Az innovációk többsége ezért a technológiai újításokhoz (olcsóbb és egyszerübb megoldásokhoz), semmint az elméletileg megalapozott elképzelésekhez kapcsolódik. 
építészek. Steets itt megint csak Gropius munkáira tér vissza. Életrajzi interjúkra alapozva az 1928-ban elkészült lapos tetős, Dessau-Törten kislakásos lakótelep belakását mutatja be. A végtelenül egyszerű belső tereket idővel tapéták, a német otthonosságot kifejező biedermeier bútorok lepték el. A racionális lakásbelsőket sem kímélték, falakat bontottak el azért, hogy a polgári lakásmódban kulcsszerepet játszó előszoba megfelelő, a vendégek fogadására alkalmas térré váljon (Steets 2015: 2127). Az ilyenfajta átalakítások világosan mutatják, hogy a térhasználók az építészeti valóságnak voltaképpen nemcsak használói, hanem létrehozói is. ${ }^{11}$

A belakás folyamata természetesen nem korlátozódik a tényleges építészeti beavatkozásokra. Erre Steets is utal, noha az iménti példák azt sugallják, hogy elméletének középpontjában a környezet anyagisága áll. Ám a belakás folyamatának az építészetről folyó diskurzus is része, sőt sok esetben itt dől el az épület jövője is. Ez a diskurzus megint csak több szálon fut, hiszen a tudományos munkákban is megjelenő professzionális értékelések mellett létezik egy hétköznapi (az írott szövegekben ritkábban megjelenő) olvasat is. ${ }^{12}$

Ezzel kapcsolatban a századforduló építészetének időben és társadalmi csoportok szerint is változó megítélésére szeretnék utalni. A 20. századi építészettörténet-írás a szecesszió és az eklektika ellenében határozta meg alapelveit. Mindez következett abból, hogy a huszadik század vezető stílusirányzata, a modernizmus részben az eklektika és a szecesszió tagadásából született. Ennek megfelelően a modern építészeti kánon hetvenes évekbeli válságáig a századfordulós építészet megítélése rendkívül rossz volt. Az elmúlt évtizedekben ugyanakkor (miközben a modern építészet maga is történeti stílussá öregedett) ez az egyoldalú értelmezés visszaszorult, és az újabb városképi elemzések már értékként tekintenek a századforduló, illetve az azt megelőző historizáló korszak épületeire (Nerdinger 2010: 17). Itt tehát arról van szó, hogy egy alapvetően változatlan (azért alapvetően, mert közben az épületek állaga romlott) építészeti környezet diskurzív olvasata változott meg. Bonyolítja a helyzetet, hogy a szakmai értékektől elszakadva a „laikus” közönség számára a szecesszió és az eklektika képviselte polgári korszak szinte mindvégig megőrizte kitüntetett szocializációs referencia jellegét. Az építészek és a laikusok ízlésvilágának különbsége végig jellemző volt a 20. századra. ${ }^{13}$

Steets tudásszociológiai értelmezésének nagy előnye, hogy az építészet kérdéskörét közelebb hozza a mai szociológiai gondolkodáshoz, amikor is az építészeti cselekvés létrejöttének mozzanataira koncentrál. Ezzel pedig a szociológia bevett módszertanának keretei között is vizsgálhatóvá teszi az építészetszociológia tárgyát. Általános probléma lehet ugyanis, hogy a Delitz-féle makroszociológiai megközelítés empirikus alkalmazásához elengedhetetlen bizonyos fokú építészettudományos látásmódra szert tenni (Németh 2019: 200). Tény, hogy Delitz esetelemzéseiben a

11 Az már további kérdéseket vet fel, hogy az építészek ezeket a beavatkozásokat rendszerint negatívan értékelik.

12 E témának szenteli kötetét Kernich (2017).

13 Csupán egyetlen, de igen sokatmondó példa e téren Mocsár László Debrecen-szociográfiájának bevezető, építészeti fejezete, ahol a régi Debrecent állítja szembe a modernizálódó, de sivárnak érzett új várossal (Mocsár 1981: 14). 
kétféle látásmód (szociológia és építészet) sikeresen egészíti ki egymást. Így például a posztfordista gazdaságszociológiai termelési módokat párhuzamosan értelmezi azokkal a designtörekvésekkel, amelyek igyekszenek a megjelenés szintjén elmosni vagy legalábbis nem kihangsúlyozni a különféle munkakörök (kékgallérosok-fehérgallérosok) és hierarchiaviszonyok (főnök-beosztott) közötti egyenlőtlenségi viszonyokat (Delitz 2009: 104). Elemzéseiből kirajzolódik, hogy a kortárs építészeti terek éppolyan normatív üzeneteket közvetítenek, mint annak idején a modernizmus, csak éppen más értékeket hangsúlyoznak. Más tanulmányok is felhívták a figyelmet arra, hogy míg korábban a rend, a megismerhetőség, a stabilitás fogalmai rendezték az épületeket, addig a mai tereinkben inkább a flexibilitás, a dinamika, az osztályok nélküli társadalom ideája érvényesül (Tutunel 2017: 25). Az építészeti tér és a társadalmi (érték)tér együttes szemléletéhez azonban ma még alig-alig kodifikáltak a módszertani eljárások. Maga Delitz is inkább esszéket ír. Mindez önmagában nem lenne probléma, ha magának az esszé műfajának a szociológián belül meglenne a survey jellegű tanulmányokkal összemérhető presztízse (Léderer 2002). Ezért fontos Steets elméletének módszertani hozadéka, hiszen utat nyit a bevált szociológiai módszerek alkalmazása előtt. Az építészek társadalomképének vizsgálata ugyanis kérdőívekkel vagy diskurzuselemzéssel is megvalósítható, akárcsak a befogadás folyamata. Ám éppen ez az előny az építészetszociológia számára egyben visszalépést is jelenthet. Hiszen hiába fogalmazza meg elméleti igényét az építészeti cselekvés egészének tárgyalására, ha az empíria továbbra is megmarad az emberek közötti interakció, a verbalizálható jelek szférájában. Steets elméletének építészetszociológiai gyengeségét éppen az épített környezet vizsgálatának háttérbe szorulása jelenti.

Másfelől közelítve, de hasonló kritikákat fogalmaz meg a két szerző kapcsán Fischer is. Delitz esetében kiemeli, hogy bár világosan állást foglal a társadalmi cselekvés fizikai (és építészeti) meghatározottsága mellett, de nem képes megragadni a konkrét, az építészeti cselekvésben megnyilvánuló társadalmai technikákat (másként fogalmazva elemzései túlságosan is építészetcentrikusak). Steets esetében pedig hiányolja, hogy bár az építészet létrejöttének egyes mozzanatait részletesen elemzi, de közben éppen az objektív valóság sajátos, csak az építészetre jellemző tulajdonsága látszik elveszni (másként fogalmazva túlságosan is szociológiai megközelítésû) (Fischer 2017: 56). Fischer szerint az építészetszociológiát az építészet immanens tulajdonságaira kell alapozni. A tanulmány következő fejezetében Fischer iménti elméleti alapvetését mutatom be részletesebben.

\section{A nehéz médium}

Fischer (2010; 2017) munkáiban következetesen a társadalmi érintkezés „nehéz” médiumának nevezi az építészetet, utalva annak helyhez kötöttségére és relatív stabilitására. Alapvetése, hogy az építészetszociológia nem egyenlő az építészet szociológiájával, tehát a figyelem nem korlátozódhat az építési folyamat interakcióira (pl. épít- 
tető-építész, publikum-múvész stb.), hanem magára az építészetre kell irányulnia. Luhmann rendszerelméletére utalva az építészetet a társadalmasodás egyik médiumának tekinti, amely a végtelenféle variáció szűkítését hajtja végre a térben: „A médiumot potenciális formaképződések végtelen horizontjaként képzelhetjük el: a tengerpart vizes homokja, melyben megjelenhetnek a lábnyomok, a levegö és a fény mint észleléseink médiumai, vagy a nyelv szavai, melyekben mondatok jelenhetnek meg. A forma a médiumban jön létre, és a médium mindig mint a forma jelöletlen oldala marad meg." (Tóth 2015: 9 értelmezésében Luhmann 2006 gondolatai; lásd továbbá Éber 2006). Az építészet azonban sajátos médium, amely különbözik minden más, szociális rendszereket létrehozó könnyű médiumtól. Miként Fischer fogalmaz: „hasznos az építészetet más rendszermédiumokhoz hasonlítani, úgymint a nyelvhez, képhez, színpadhoz, szoborhoz, plasztikához vagy a zenéhez, de ez a szóhasználat - éppen a szociológia számára - azzal a veszéllyel jár, hogy az épitészet speciális szociális dimenzióját veszítjük szem elől." (Fischer 2017: 57)

Fischer másik kiindulópontja Plessner (1975) filozófiai antropológiája, az úgynevezett excentrikus pozicionalitás. Az élettelen világgal szemben az élőlények igyekeznek elkülönülni környezetüktől, határt vonnak saját létezésük köré. Az állatoknál mindezek a funkciók jórészt öröklöttek, miközben az embernél ez tanult és önreflexív folyamat (azaz az ember képes saját magát is önmaga környezeteként látni). Plessner szerint az ember minden esetben „félkész” élőlény, amely a társadalmi környezet révén formálódik. Plessner az excentrikus pozicionalitást a test mesterséges és tudatos kiterjesztéseként ábrázolja, ami a ruházat esetében a legnyilvánvalóbb. Fontos látni, hogy itt a biológiai test és annak mesterséges kiegészítése szociális üzenettel is bír. Egy kabát például véd a hideg ellen, de társadalmi státuszt, értékrendet, identitást is jelöl. Hasonló a helyzet az építészettel is, csak jóval nagyobb léptékben. A ruha után az építészet az emberi bőr „harmadik” fokú kiterjesztése. Az épület egyszerre elhatárol, és a kapuk révén kontrollált kapcsolatokat hoz létre a társadalom tagjai között.

Fischer szerint tehát az építészet első számú szociológiai sajátossága, hogy térben megfogható, stabil határokat biztosít a társadalom tagjainak és intézményeinek. És hogy ennek mi a sajátossága, azt a nyelvvel való összevetés kapcsán érthetjük meg igazán: „Az ember belső világát és külső környezetét folyamatosan szabályozza, rendezi. Ilyen rendezó eszköz lehet a nyelv, amely azonban a lélegzethez kötött és leheletkönnyú eszköz, ellentétben a test biológiai határaitól elszakadó építészettel, amely nehéz és stabil." (Fischer 2017: 59). Az építészet tehát mindenekelőtt hozzájárul a rendszer és környezete közötti határ stabilitásához (pl. ház-kert, telek-utca, falu-határ), ezzel pedig egyszerúsíti, hierarchikusan szervezi és átláthatóvá teszi a környezetet. Fischer gondolatát egy példával illusztrálnám: az iskolával. Azzal, hogy az iskola épülete térben elhatárolódik a környezetétől, a gyerekeket érő társas ingereket is képes kontrollálni. Ezzel pedig hozzájárul az oktatási rendszer önállósodásához, saját magát felépítő képességéhez, autopoéziséhez. 
Fischer (2017: 59) szerint az építészet második számú sajátossága, hogy bejárhatósága miatt feloldódik benne a cselekvő és a tárgy karteziánus értelemben vett elkülönülő viszonya. Egy szerszám, ruhadarab vagy más, az ember biológiai képességeit kiegészítő, az emberi cselekvést technicizáló tárggyal szemben az építészet egyszerre lehet a cselekvés tárgya és foglalata is. Harmadik pontként az építészetet mint hangulatteremtő médiumot említi. A hangulatteremtő médiumok között azonban megint csak sajátos helyet foglal el. Fischer a zenét hozza fel példaként, amely időben korlátozott, míg az építészet (legalábbis a zenével összehasonlítva) állandó, mozdulatlan, igen lassan változó. Ebből következik, hogy az építészet nemcsak hangulatkeltő, de generációkon átívelő stabilitásélményt is nyújt.

A generációkon átívelő jelleg az építészet negyedik szociológiai tulajdonsága. Baecker-t (2015: 70) idézve olvashatjuk Fischernél: „Egyetlenegy fal, ajtó, ablak sem lehet társadalmilag közömbös. Irányítanak, ellenőrizik a ki-és bejárást, meghatározzák a tájékozódási pontokat. Mindez folyamatos reakciót, döntéseket igényel a tekintetben, hogy elfogadjuk-e vagy elutasitjuk-e az épitett környezet sugallta cselekvésmintát." (Fischer 2017: 61). Az építészeti környezet tehát voltaképpen megelőzi a cselekvés bármely egyéb szintjét, hiszen már akkor (és azután is) ott van, hogy az ember belép bármilyen további társas interakcióba.

Fischer gondolatait folytatva ennek az állításnak a relevanciája sehol nem érvényesül jobban, mint a régészetben, ahol az épületromoknak sokszor más médiumok nélkül kell megjelenítenie elmúlt társadalmi rendszereket. Ám éppen a régészet a példa arra is, hogy az épített környezet önmagában hiányos, néha pedig teljesen értelmezhetetlen. Ráadásul még az álló épületek esetében sem egyértelmű azok rendszeralkotó képessége (lásd bővebben Trebsche et al. 2010). Az építészet tehát véleményem szerint nemcsak sajátosan nehéz médium, hanem - a nyelvi kommunikációval összevetve legalábbis - hiányos médium is. Márpedig ha elfogadjuk, hogy az építészet nem képes a nyelvi struktúrákkal összevethető komplexitású rendszert létrehozni, felmerül a kérdés, vajon az építészeti cselekvés fogalma helyettesítheti-e a szociológiában a társadalmi cselekvés weberi definícióját. A válasz inkább nem, ám ekkor egy újabb kérdés is felmerül, nevezetesen az, hogy az építészetszociológia miként viszonyuljon a szociológia jó évszázadon át kodifikált tudományterületéhez.

\section{Az építészetszociológia helye}

Fischer (2017: 57) és Delitz (2009: 120) nem kevesebbet állít, mint hogy az építészetszociológiát a szociológiai megismerés központi paradigmájává kellene tenni. Úgy vélem, hogy noha a tudományterület kijelölésének folyamatában fontos a célok megfogalmazása, némileg túlzó ez a kívánalom. Nemcsak azért, mert nincsenek meg ennek az intézményi feltételei. A szociológia ugyanis a maga sajátos cselekvésfelfogásával mélyen beágyazódott a tudományterületek közé, nincs szüksége ilyen mértékú paradigmaváltásra. Másrészt az építészetszociológia kibontakozásához meglátásom 
szerint nem a szociológiai megismerés centrumát kell megcélozni, hanem annak interdiszciplináris határterületeit megerősíteni.

Az idézett szerzők azon gondolata, hogy az építészeti környezet felismerése és tudatosítása módosíthatja, kiegészítheti a társadalmi cselekvésről alkotott általános szociológiai fogalmainkat, önmagában megállja a helyét. Ám azt is látni kell, hogy bármennyire is a szociológia lényegét érintő kérdésről van szó, már számos paradigmaváltás lezajlott anélkül, hogy a szociológia lényege megváltozott volna. Elég csak a hálózatelméletekre utalni, illetve a témánk szempontjából különösen érdekes Latourféle (1992) társulások szociológiájára, amely egyébiránt az építészetszociológusok által is gyakran hivatkozott elmélet (Szabari 2007). A Latour-féle Actor-Network Theory (társulások szociológiája) a weberi cselekvésfelfogás kritikájából indul ki, azt állítva, hogy végső soron nem az egyén és a cselekvés maga, hanem a hálózat és a hálózatban lezajló „cselekmény” a fontos. A hálózatnak pedig nemcsak személyek, hanem tárgyak is részesei lehetnek. Ez a paradigmaváltás azonban azzal a nem kívánt következménnyel járhat, hogy „a latouri cselekvő körülhatárolása bizonytalanná” válik (Szabari 2007: 114). Nem történhet-e valami hasonló elbizonytalanodás a cselekvő építészet fogalma körül?

Utaltam rá, hogy az építészetszociológiai elméletek empirikus alkalmazásakor a legtöbb esetben a már bevált módszertani eljárásokat alkalmazzák, így például interjúkat, diskurzuselemzéseket (lásd Fischer-Delitz 2009). Márpedig ezek az eljárások a bevett szociológiai cselekvéselméletekre épülnek, és arra keresik a választ, miként hozzák létre, érzékelik, használják és interpretálják az emberek környezetüket (legyen szó embertársaikról, intézményekről vagy éppen az épített világról). Sokszor úgy tûnhet, hogy az esettanulmányokat olvasva nem új tudományos paradigma születését látjuk magunk előtt, hanem egy új szakszociológiáét.

Az elméletek által felvázolt építészetszociológia akkor jöhet csak létre, ha - miként arra Fischer is felhívta a figyelmet - a szociológia mellett az építészet is egyenlő súllyal szerepel. Ehhez azonban nemcsak a szociológiai cselekvés fogalmat kell kiegészíteni, hanem az építészetet is újra kell definiálni - miként Delitz javasolta munkáiban. Az építészetszociológiai kutatás számára ugyanis nem az egyes épületek vagy városképek kvalitása, netán múvészi kifejeződése a fontos, hanem a környezet egésze. Különösen jelentősek a tömegjelenségek, így például a családiház építkezések, a kevésbé nívós „külvárosi" bérházépítkezések, a kisarchitektúrák, például az üzletportálok kialakítása, a feliratok. Mindezek a kérdések pedig részben már átvezetnek újabb területekre, például a vizuális szociológiához (Sztompka 2009: 13). Az építészet e kevésbé rangos tömegjelenségei aligha vizsgálhatók a múvészettörténet-írás módszereivel.

$\mathrm{Az}$ imént felvetett probléma a rangos és a tömeges építészet között nem ismeretlen az építészeti kutatásokban sem. Korábban a népi építészet vetett fel hasonló dilemmákat, hiszenolyan alig-építményeket kellett tárgyalnia (például istállóként használt deszkabódékat, primitív ágasfás veremházakat), amelyek első ránézésre nem állnák meg a helyüket a középkori katedrálisokat és barokk templomokat felvonulta- 
tó gyűjteményekben. A probléma áthidalását segítette a modern építészet funkcióforma összetartozását hangsúlyozó alaptézise, amely a népi építészet egyszerű szerkezeteit az adott élethelyzetben elérhető legracionálisabb megoldásként mutatta be (lásd például Tóth 1961). Észre kell venni, hogy ez az érvelés voltaképpen szociológiai jellegú, hiszen egy adott társadalmi csoport (parasztság) időben változó életmódját, munkakörülményeit, technikai tudását és technikai kultúráját írja körbe.

De nemcsak az építészettörténet-írás halmozott fel építészetszociológiai téziseket, hanem más rokon tudományok is. Így például a történettudományban vagy a földrajztudományban is találhatunk egy-egy, a maguk szakterületét tekintve szintén a határon lévő (vagy azon túl tekintő) munkát. Csak illusztrációképpen érdemes Elisabeth Lichtenberger (2011) nevét megemlíteni, aki széles körben használt városföldrajzi összefoglaló munkájában egy szociológiai fogalmat, a szegregációt kapcsolta össze a városformák időben és politikai rendszerek szerint változó mintázataival.

A további tudományterületi példák mégoly vázlatos számbavétele is önálló tanulmányt igényelne. Ami azonban kiemelendő, hogy az építészetszociológiai elméletalkotás számára nemcsak a bevett szociológiai fogalmak állnak rendelkezésére, hanem interdiszciplináris területként támaszkodhat az építészet, a néprajz, a földrajz, a történettudomány, a környezetpszichológia, a kulturális antropológia vagy akár az irodalomtudomány, a filozófia eredményeire is. Ezért nem lényegtelen, hogy az építészetszociológiát a szociológiai kutatások fő sodrában (és ezzel az építészettől és a rokon tudományoktól relatíve távol) vagy annak határmezsgyéjén, de az épített környezettel foglalkozó többi tudományhoz relatíve közel helyezzük el. ${ }^{14}$ Ahhoz tehát, hogy létrejöjjön a hazai építészetszociológiai mező, nem elég a szociológián belüli ismereteket újraértelmezni. Mindenekelőtt számba kell venni azokat a tudományos eredményeket, amelyek a szociológián kívül születtek ugyan, de építészetszociológiai relevanciával bírnak. Másodszor pedig olyan új kutatási kérdések kellenek, ahol egy közös tárgy, helyszín, épület, probléma kapcsán több tudományterület együttmúködik. Így remélhető, hogy feltárulnak az építészet mélyebb társadalmi összefüggései, illetve hogy az építészetszociológia hosszú távon képes lesz integráló, összekötő szerepet betölteni a humán alapú építészetkutatás területén. ${ }^{15}$

\footnotetext{
Abstract: The study analyses the relationship between architectural sociology and sociology. It focuses on the central issue of the so called "architectural action". According to the concept of architectural action the built environment is not only a background, stage or imprint of social relations, but it is an actor itself within the social interactions. Thus, the architecture cannot be a neutral actor in the society: it defines hierarchical relations, segregation processes or social roles. Similar to other mediums of the culture (for example the language) architecture is part of the sociological processes. The paper builds upon the theories
}

14 További érdekes kérdéseket vetne fel, miként érdemes kezelni a tudományok közötti átjárhatóságot. A posztmodern tudományfelfogások elvetik a korábbi szakterületekre jellemző kizárólagosságot, és olyan fogalmakat vezetnek be, mint az ambivalencia-reflexió, dekonstrukció, tetralemma (bővebben lásd Sárkány 2014: 159).

15 Erre a feladatra jött léte a szerző által vezetett „Térformák - Társadalomformák” könyvsorozat és kutatómühely, amely 2020 tavaszáig hat kötetet gondozott, és ugyanennyi kötetre való elökészítő konferenciát szervezett meg. Lásd bővebben: https:// tertar.webnode.hu (letöltés: 2020. április 04. 16.) 
of three authors. According to Delitz, all social institutions not only have architectural forms, but these social forms cannot exist without a spatial dimension. Delitz suggests that the subject of architecture should be extended into a more comprehensive notion of the built environment. The architecture as art cannot answer all the sociological aspects. The theory of Steets starts from the micro level and she wants to grasp the essence of architectural action through the triad of the formation, reception and objectification (socialisation). Steets' merit is that she opened a wide door for the usual sociological methods in architecture sociology. Finally, in addition to the two authors, Fischer aims to understand the peculiarities of architecture. He means that the architecture is a timeless and stable social medium compared to other media like language or music. The common conclusion of the three theories is that Weber's concept of social action has to be rethought and the material dimension of the social life should be more reflected. Even more they argue that sociology should redefine its subject. On the contrary this paper argues for an interdisciplinary approach, which is able to interpret and integrate all the neighbouring fields (like urban geography, ethnography of rural dwellings, environment psychology) which deals with the human aspects of the architecture.

Keywords: architecture sociology, architectural action, built environment, human aspects of the architecture

\section{Irodalom}

Baecker, D. (2015): Die Stadt der Unbekannten. In: Archithese Bd. 2., 66-71.

Berger, P. L. - Luckmann, T. (1988): A valóság társadalmi felépitése. Tudásszociológiai értekezés. Ford. Tomka M. Budapest: Jószöveg Múhely.

Berger V. (2018): Térré szôtt társadalmiság. A tér kategóriája a szociológiaelméletekben. Budapest: L’Harmattan Kiadó és Könyvpont Kiadó.

Berki M. (2014): Széttöredezve - a soroksári úti ipari terület funkcionális fragmentációja. Kultúra és Közösség, 5(2): 43-56.

Brenner, J. (2017): The face of German democracy: parliament and government buildings in Berlin. Belvedere Meridionale, 29(4): 194-199.

Bobek, H. - Lichtenberger, E. (1966): Wien, Bauliche Gestalt und Entwicklung seit der Mitte des 19. Jahrhunderts. Wien: Verlag Hermann Böhlaus.

Csanádi G. - Csizmady A. - Kocsis J. B. - Kőszeghy L. - Tomay K. (2010): Város tervező társadalom. Budapest: Sík Kiadó.

Csizmady A. (2008): A lakóteleptôl a lakóparkig. Budapest: Új Mandátum Kiadó.

Csurgó B. (2014): A vidék nosztalgiája. Kulturális örökség, turizmus- és közösségszervezés három észak-alföldi kistérségben. Socio.hu Társadalomtudományi Szemle, 4(2): 1-20.

Davis, M. (1999): Los Angeles, az erődváros: a városi tér militarizációja. Budapesti Negyed, 7-8(4-1): 27-50.

Delitz, H. (2008): Architektur, Artefakt, Kreativität: Herausforderungen soziologischer Theorie. In Rehberg, K.-S. (Hg): Die Natur der Gesellschaft: Verhandlungen des 33. Kongresses der Deutschen Gesellschaft für Soziologie in Kassel. Frankfurt/ New York: Campus. 
Delitz, H. (2009): Architektursoziologie. Bielefeld: transcript. (= Einsichten Themen der Soziologie)

Delitz, H. (2010): Gebaute Gesellschaft. Architektur als Medium des Sozialen. Frankfurt/ New York: Campus.

Éber M. Á. (2006): Komplexitás redukálva. BUKSZ, 18(4): 333-342.

Eßbach, W. (2001): Antitechnische und antiästhetische Haltungen in der soziologischen Theorie. In Lösch, A. - Schräge, D. - Spreen, D. - Stauff, M. (Hg.): Technologien als Diskurse. Konstruktionen von Wissen, Medien und Körpern. Heidelberg: Synchron, 125-138.

Farkas Z. (2006): A racionális cselekvés, a társadalmi cselekvés és kölcsönhatás. Miskolc: Miskolci Egyetem. (= Társadalomelmélet 5.)

Fischer, J. (2010): Architektur als „schweres Kommunikationsmedium“ de Gesellschaft. Zur Grundlegung der Architektursoziologie. In Trebsche, P. Müller-Scheeßel, N. (Hg.): Der gebaute Raum. Bausteine einer Architektursoziologie vormoderner Gesellschaften. Münster-New York-München-Berlin: Waxmann, 63-82.

Fischer, J. (2017): Gebaute Welt als schweres Kommunikationsmedium der Gesellschaft. Architektur und Region aus architektursoziologischer Perspektive. In Karstein, U. - Schmidt-Lux, T. (Hg.): Architekturen und Artefakte. Zur Materialität des Religiösen. Wiesbaden: Springer, 49-69.

Fischer, J. - Delitz, H. (Hg.) (2009): Die Architektur der Gesellschaft. Theorien für die Architektursoziologie. Bielefeld: transcript Verlag. (= Sozialtheorie)

Helms, H. G. (1992): Die Stadt als Gabentisch. Beobachtungen der aktuellen Städtebauentwicklung. Leipzig: Reclam-Verlag.

Hidas Z. (2013): A tér szociológiai felfedezése. In Pannonhalmi Szemle, 21(4): 35-45.

Karstein, U. - Schmidt-Lux, T. (Hg.) (2017): Architekturen und Artefakte. Zur Materialität des Religiösen. Wiesbaden: Springer. (= Veröffentlichungen der Sektion Religionssoziologie der Deutschen Gesellschaft für Soziologie)

Keller, M. (2017): Szocialista lakhatás? A lakáskérdés az 1950-es években Magyarországon. Budapest: L’Harmattan - OSZK.

Kernich, S. (2017): Alltägliche Architektur. Die gebaute Umwelt in unserer Alltagswirklichkeit. Konstanz-München: UVK.

Kőszeghy L. (2019): Társadalmi részvétel a magyarországi várostervezésben, tervezésszociológiai megközelítésben. In: Belügyminisztérium, Önkormányzati Koordinációs Iroda (szerk.): A helyi önkormányzatok fejlödési perspektivái Közép-Kelet Európában: Közös tanulás és innovációk / Perspectives of Local Governments in CentralEastern Europe: Common Learning and Innovations. Budapest: Belügyminisztérium Önkormányzati Koordinációs Iroda: 70-89.

Latour, B. (1992): Where are the missing masses, sociology of a few mundane artefacts. In Bijker, W. E. - Law. J. (eds.): Shaping Technology / Building Society. Studies in Sociotechnical Change. Cambridge: MIT Press: 225-259. 
Léderer P. (2002): A szociológus, a módszerei, meg a szövege. Rögeszme-félék a mesterségrôl. Budapest: Új Mandátum Kiadó.

Lichtenberger, E. (2011): Die Stadt: Von der Polis zur Metropolis. Darmstadt: Wissenschaftliche Buchgesellschaft.

Löw, M. (2001): Raumsoziologie. Frankfrurt am Main: Suhrkamp.

Luhmann, N. (2006): Bevezetés a rendszerelméletbe. Budapest: Gondolat Kiadó. (= Társadalomtudományi Könyvtár)

Meggyesi T. (2009): Városépitészeti alaktan. Budapest: Terc.

Miklóssy E. (1995): A Hungária körút átalakulása. Budapesti Negyed, 9(3). http://epa. oszk.hu/00000/00003/00008/miklossy.htm (letöltés: 2020. április 16.)

Mocsár G. (1981): Délibábjaim városa. Budapest: Magvető Kiadó. (= Magyarország Felfedezése)

Németh K. (2019): A helyek szellemétől a terek erejéig. A kortárs szépirodalom szociografkus olvasata. In Kollár Á. - Tamáska M. (szerk.): A genius loci. Irodalom és építészet. Budapest: Martin Opitz Kiadó, 193-218. (= Térformák-Társadalomformák: TérTár kötetek 5.)

Nerdinger, W. (2010): Warum wurde und wird rekonstruiert - Rekonstruktion als politische, ideologische oder ästhetische Handlung. In Hassler, U. - Nerdinger, W. (Hg.) Der Prinzip Rekonstruktion. Zürich: ETH Hochschulverlag, 14-63.

Plessner, H. (1975 [1928]): Die Stufen des Organischen und der Mensch. Einleitung in die philosophische Anthropologie. Berlin: de Gruyter.

Sárkány P. (2014): A filozófia mint praxis. Tanulmányok a filozófia, a pszichoterápia és a szociálpedagógia határterületeirôl. Budapest: L'Harmattan - Sapientia.

Schäfers, B. (2003): Architektursoziologie. Grundlagen-Epochen-Themen. Wiesbaden: Springer.

Schäfers, B. (2012): Architektur. In Eckardt F. (Hg.): Handbuch Stadtsoziologie. Wiesbaden: Springer, 365-377.

Simmel, G. (1957): Brücke und Tür. Essays des Philosophen zu冈 Geschichte, Religion, Kunst und Gesellschaft.Michael Landmann (Hg.) Stuttgart: K. F. Koehler.

Steets, S. (2015): Der sinnhafte Aufbau der gebauten Welt. Eine Architektursoziologie. Berlin: Suhrkamp. (= Einsichten Soziologische Themen)

Szabari V. (2007): A társulások szociológiája. Szociológiai Szemle 1-2: 109-118.

Szelényi I. (1973): Városszociológia. Budapest: Közgazdasági és Jogi Kiadó.

Sztompka P. (2009): Vizuális szociológia. A fényképezés mint kutatási módszer. Budapest - Pécs: Gondolat Kiadó - PTE Kommunikáció- és Médiatudományi Tanszék.

Tamáska M. (2018): Metropolen. Bécs Budapest Wien. Pralelle Stadträume aus dem 20. Jahrhundert / Párhuzamos városképek a 20. századból. Salzburg-Wien: Müry Salzmann.

Tóth B. (2015): A tudomány, mint funkcionálisan elkülönült társadalmi alrendszer. A tudomány rendszerelméleti megközelítése. Szeged: Szegedi Tudományegyetem.

Tóth J. (1961): Népi épitészetünk hagyományai. Budapest: Műszaki Könyvkiadó. 
Trebsche, P. - Müller-Scheeßel, N. / Reinhold, S. (2010): Der gebaute Raum Bausteine einer Architektursoziologie vormoderner Gesellschaften. Münster-New York-München-Berlin: Waxmann. (= Tübinger Archäologische Taschenbücher 7.)

Tutunel, P. (2017): Nem csupán egy tégla a falban: a tanító tér. In Sárkány P. - Tamáska M.: A tanulás helyei: iskolaépítészet. Budapest: Martin Opitz Kiadó, 15-31. (= Térformák-Társadalomformák: TéTár kötetek 1.)

Will, T. (2008): Geschichtsbuch oder Stadtsalon? Der Wiederaufbau des Dresdner Neumarkts aus der Sicht von „Modernisten” und „Traditionalisten”. Wissenschaftliche Zeitschrift der Technischen Universität Dresden, 57(3-4) (2008): 126-130. 